5. Онопрієнко С. Г. Класифікація елементів інформаційної культури // Форум права, 2016. № 5. С. 135-138. URL: http://nbuv.gov.ua/UJRN/ FP index.htm_2016_5_24. (дата звернення: 12.04.2021)

6. Арістова І.В., Бєляков К.І., Колпаков В.К. та ін. Юридична відповідальність за правопорушення в інформаційній сфері та основи інформаційної деліктології : монографія. Київ : КВІЦ, 2019. 344 с.

References

1. On information: Law of Ukraine of October 2, 1992 № 2657-XII. URL: https://zakon.rada.gov.ua/laws/show/2657-12\#Text [In Ukrainian]

2. Koropatnik, I.M. (2016) Problems of information support of the activity of civil-military cooperation groups of the Armed Forces of Ukraine. Rule of Law, 1. http://sd-vp.info/2016/problemi-informat. [In Ukrainian].

3. Onopriienko, S.H. (2021) Vectors of development of legal regulation of information security. Science and innovations in the 21 st century: materials of the First All-Ukrainian Internet Conference of Students and Young Scientists (Melitopol, May 12, 2021). URL: http://elar.tsatu.edu.ua/bitstream/ $123456789 / 14363 / 1 / \% \mathrm{D0} \% 9 \mathrm{~A} \% \mathrm{D0} \% \mathrm{BE} \% \mathrm{D0} \% \mathrm{BD} \% \mathrm{D} 1 \% 84 \% \mathrm{D0} \% \mathrm{~B} 5$

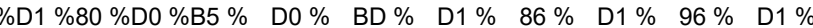
8F_2021_\% D0 \% A22.pdf \# page = 143 [In Ukrainian]

4. Shopina, I.M. (2017) Information and psychological influences as a category of information law: concepts, features, features of research. Science and law enforcement, 4; 134-140. [In Ukrainian].

5. Onopriienko, S.H. (2016) Classification of elements of information culture. Law Forum, 5, 135-138. URL: http://nbuv.gov.ua/UJRN/ FP_index.htm_ 2016_5_24. [In Ukrainian].

6. Legal responsibility for the offense in the information sphere and the basics of information tort: a monograph (2019) / Aristova I.V., Belyakov K.I., Kolpakov V.K. etc. Kyiv: KVIC, 2019. 344 p. [In Ukrainian]

Надійшла до редколегії 22.07.21

V. Volovyk, PhD Stud.

ORCID ID 0000-0003-0519-4353

Interregional Academy of Personnel Management, Kyiv, Ukraine

\title{
INFORMATION AND LEGAL BASES OF PREPARATION OF CITIZENS FOR MILITARY SERVICE
}

The purpose of the article is to determine the essence and elements of information and legal training for military service. The article substantiates that in order to ensure a high level of development of information security and information culture of servicemen, it is necessary to form in them sufficient knowledge, skills and abilities to ensure personal and corporate information security. Attention is focused on the importance of the use of the information space by military personnel for more effective performance of their service and combat missions. The implementation of the tasks defined above is possible provided that the preparation of civilians for military service includes components of training and practicing skills necessary for the effective implementation of the information component of their future professional activities. Information activity is considered, in which a soldier participates, in a structural aspect. Three blocks of the studied phenomenon are highlighted: firstly, this is a block of information and legal knowledge, which should include the most important provisions of the legislation of Ukraine on access to public information, protection of personal data, protection of state secrets, as well as the peculiarities of working with information requests from citizens and the basics of electronic workflow. Secondly, this is an information security block, which consists of three main elements: information security of an individual, information security of the Armed Forces of Ukraine and information security of the state. Thirdly, this is a block of information hygiene, which includes the development of skills and abilities to maintain the psychological balance of a serviceman in situations of aggressive communicative influences, the ability to understand the purpose of disseminating information, to highlight false information, the purpose of which is to achieve military and non-military goals of the enemy. The article establishes that the system of information and legal training for military service should include the formation of relevant knowledge, abilities, skills and personal qualities. This can be achieved through the introduction of special courses in the system of military lyceums, as well as the introduction of a system of disciplines on the basis of higher military educational institutions and military educational subdivisions of higher educational institutions, providing for the acquisition of basic information and legal knowledge, skills and abilities. In addition, approaches to the formation of professional standards for all military registration specialties, educational and professional programs and curricula should be revised by including in them the relevant competencies in the field of information security, information hygiene and information legislation, each of which is of indisputable importance for the formation of personality. a modern serviceman as an educated, knowledgeable and information literate person who can use all the possibilities of the information space for the effective fulfillment of his service and combat missions.

Keywords: information and legal support, military service, serviceman, information hygiene, information security, information space.

УдК 342.92

DOI: https://doi.org/10.17721/1728-2217.2021.47.48-51

Д. Дегтярьов, ст. викладач mega.degdd@ukr.net ORCID ID 0000-0002-2512-6967

Київський національний університет імені Тараса Шевченка, Київ, Україна

\section{ПРЕДМЕТ ДЕМОКРАТИЧНОГО ЦИВІЛЬНОГО КОНТРОЛЮ НАД СИЛАМИ ОБОРОНИ}

Розкрито поняття та особливостей демократичного цивільного контролю над силами оборони. 3'ясовано, що правовідносини, що виникають під час закріплення та визначення предмета демократичного цивільного контролю мають комплексний характер і регулюються нормами різних галузей права. Виокремлено зовнішні прояви активності вказаних посадових осіб, які піддаються вимірюванню, узагальненню та аналізу. Одним із таких проявів є поведінка осіб, на яких поширено законодавчі положення про здійснення демократичного цивільного контролю над силами оборони. Предмет демократичного иивільного контролю над силами оборони - елемент діяльності об'єктів контролю, який безпосередньо охоплюеться організаційною поведінкою як військових посадових осіб, так й інших категорій військовослужбовців та працівників військових формувань, а також цивільних осіб, які законами Украӥни наділені повноваженнями безпосередньо приймати рішення, які стосуються сил оборони. Предмет демократичного цивільного контролю над силами оборони має відповідати таким вимогам: об'єктивність, вимірюваність, конкретність, повторюваність результатів у разі застосування іншими суб'єктами контролю тієї ж самої методології контролю і має джерелом свого походження суспільні відносини, які виникають у секторі безпеки та оборони. Співвідношення між об'єктом і предметом вказаного контролю обумовлюється масштабом діяльності, яка здійснюється для досягнення цілей контролю. При цьому предмет демократичного цивільного контролю над силами оборони завжди менше за своїм масштабом, ніж його об'єкт. Проаналізовано, що достатнє нормативно-правове підгрунтя для реалізації визначених вище вимог ще не створено. Прогалини у правовому регулюванні відносин, пов'язаних з контрольною діяльністю у секторі безпеки і оборони, вимагають свого заповнення. Вказане потребує внесення змін і доповнень до Закону України "Про національну безпеку", спрямованих на конкретизацію системи оцінювання результатів контролю за діяльністю сил оборони.

Ключові слова: демократичний цивільний контроль, сили оборони, сектор безпеки і оборони, правове забезпечення, правове регулювання, об'єкт контролю, предмет контролю, суб'єкти контролю.

Постановка проблеми. Проблематика, пов'язана із визначенням предмета демократичного цивільного контролю над силами оборони, останнім часом привертає до себе активну увагу науковців та практиків. Це пов'язано з тим, що амбітні завдання, які поставив перед нашою державою вектор руху на європейську та північноа- 
тлантичну інтеграцію, обумовлюють необхідність кардинального удосконалення системи контролю сектора безпеки й оборони. Окрім того, численні корупційні скандали, які пов'язують із процесами, що відбуваються в оборонній сфері, порушення правових приписів деякими особами, часто використовуються для того, щоб надати переваги певній політичній силі. Отже, практика потребує унеможливлення ситуацій, коли звинувачення у вчиненні корупційних правопорушень висуваються до військових посадових осіб, не будучи підкріплені жодними фрактами, і водночас слід визнати існуючу систему контролю у царині відповідних правовідносин недостатньо досконалою, що потребує її рефрормування. Вказані положення набувають особливої важливості під час визначення сутності та меж предмету демократичного цивільного контролю над силами оборони, що й обумовлює актуальність теми цієї статті.

Аналіз останніх досліджень і публікацій. Питання сутності демократичного цивільного контролю над силами оборони підіймали у своїх роботах багато авторів, зокрема: І. Коропатнік, О. Кобзарь, О. Комісаров, Ю. Курилюк, В. Настюк, І. Остапенко, В. Пашинський, О. Савинець, Н. Христинченко, І. Шопіна та інші. Разом з тим предмет демократичного цивільного контролю ще не здобув належного методологічного обґрунтування, що обумовлює спрямованість наукових розвідок.

Метою статті $€$ визначення поняття та окреслення особливостей демократичного цивільного контролю над силами оборони.

Виклад основного матеріалу. Соціальний контроль у сучасному суспільстві $€$ невід'ємною ознакою правової соціальної держави. Феноменологія соціального контролю сягає своїм корінням в античну філософрію, представники якої надавали великого значення можливості держави і суспільства використовувати різноманітні засоби впливу на делінквентну поведінку індивідів. Однак створення термінологічної бази та методологічного апарата соціального контролю пов'язують з настанням епохи постмодерну, для якої характерні глобалізація фрінансових, транспортних, міграційних, технологічних потоків; "віртуалізація" життєдіяльності, релятивізм тощо [1, с. 448].

Правовідносини, які виникають під час закріплення та визначення предмета демократичного цивільного контролю, як одного із різновидів соціального контролю, мають комплексний характер і регулюються нормами різних галузей права. У теорії права правові феномени, певні правові явища та процеси традиційно розглядають як нерозривну цілісність суб'єктів, об'єктів та предметів, не $€$ винятком і сфрера контролю. Контрольна діяльність $€$ спеціальним видом діяльності уповноважених суб'єктів, що спрямований на пошук, аналіз, групування та класифікацію порушень норм, правових або інших у певній сфері, оскільки існують сфери суспільних відносин, які досить слабко регулюються правом (напр., релігійні відносини, художня творчість тощо). Певні види контрольної діяльності передбачають пошук та визначення не правових, а інших соціальних норм (релігійних, естетичних тощо). Безумовно, сфрера діяльності сил оборони є достатньо детально регламентованою правом, тому в ній спостерігається переважання правових приписів як певного орієнтиру здійснення контрольної діяльності. Хоча, безумовно, питання, пов'язані з військовим мистецтвом, застосуванням військових стратегій і тактики знову-таки регулюються не стільки правовими нормами, скільки умовами ведення бойових дій і містять у собі воєнні ризики.

Отже, правове регулювання функціонування сил оборони передбачає достатньо детальну регламентацію їхньої діяльності правовими нормами. Разом з тим, певні аспекти їхньої активності регулюються іншими видами соціальних норм, зокрема, нормами військового мистецтва, моралі, корпоративної етики тощо.

Даючи визначення сутності предмета будь-якої правової діяльності, у тому числі, і контролю, вчені зазвичай виходять $з$ аксіоми про те, що предмет є частиною об'єкта. Загалом існують декілька позицій з цього приводу. Відповідно до першої з них предмет являє собою автономізовану особливу частину об'єкта. Згідно з другим підходом предмет є деталізацією тих суспільних відносин, які входять до складу об'єкта. Відповідно до третього підходу предмет ототожнюється з об'єктом, їх використання як правових термінів обумовлюються масштабом певного наукового правового дослідження.

На нашу думку, між вказаними позиціями немає принципової різниці, оскільки об'єкт і предмет сприймаються як явища одного плану. Виокремлення певних їхніх елементів $€$ абстрагуванням, яке у кожного дослідника може мати свої особливості. Отже, предмет демократичного цивільного контролю над силами оборони є, на нашу думку, складовою суспільних відносин, які є частиною об'єкта вказаного контролю.

Заслуговує на увагу питання щодо того, який саме прояв дій або бездіяльності об'єкта контролю може бути використаний як предмет моніторингу. Висуваються припущення, що об'єктом контролю $є$ посадові особи органів державної влади та місцевого самоврядування, військових фрормувань та інших суб'єктів. Така думка, на наш погляд, не зовсім коректна, оскільки посадові особи та інші працівники підприємств, установ та організацій мають надзвичайно широкий спектр залучання своїх зусиль у приватній, професійній та службовій сферах. Наприклад, посадова особа може одночасно приймати рішення щодо розподілу бюджетних коштів у секторі безпеки і оборони і водночас займатися творчою, науковою, викладацькою діяльністю. Очевидно, що із наведених видів діяльності предмет демократичного цивільного контролю над силами оборони охоплює лише перший. Для коректного визначення предмета досліджуваного виду контролю, як нам здається, необхідно виокремити зовнішні прояви активності вказаних посадових осіб, які піддаються вимірюванню, узагальненню та аналізу. Одним із таких проявів $€$ поведінка осіб, на яких поширюються законодавчі положення про здійснення демократичного цивільного контролю над силами оборони. "Реалізація правових норм у реальній поведінці людини - це складний соціально й індивідуально-психологічний процес. Поведінку людини регулює її свідомість, дієвий характер якої випливає з принципу єдності свідомості і діяльності: діяльність людини обумовлює формування ії̈ свідомості, психічних процесів і властивостей, які, у свою чергу, регулюють цю діяльність та $є$ умовою її адекватного виконання" [2, с. 77], - справедливо зазначають Р. Захарченко та Н. Теремцова. Зауважимо також, що для визначення предмета контролю значення має не будь-яка, а організаційна поведінка.

Слід сказати, що організаційна поведінка $є$ одним із проявів взаємодії людини (громадянина, особистості, працівника, посадової особи) та організації. Терміном "організація" описують стан людських систем (утворень), за якого досягають певного порядку. Поведінка, що формується в організації (фірмі, підприємстві), є її характеристикою і називається організаційною поведінкою. Організаційна поведінка ґрунтується на основних ідеях про природу людини й організацій. Теоретичними основами організаційної поведінки $є$ орієнтація на людські ресурси, ситуацію, результати і системний підхід. Орієнтований на людські ресурси підхід передбачає розвиток здібностей працівників і надання їм можливостей для їхньої реалізації, що безпосередньо веде до підвищення їхньої 
працездатності і ступеня задоволення працею. При ситуативному (ситуаційному) підході аналізують умови, які склалися в організації [3, с. 10].

Ще раз наголосимо на необхідності дотримання під час визначення предмета демократичного цивільного контролю такої вимоги, як вимірюваність. Некритичне включення до предмета контролю всіх явищ та процесів оточуючої дійсності призводить до штучного розширення його меж, згідно з чим процес контрольної діяльності набуває декларативного характеру. Зокрема, ми не можемо погодитися з думкою Н. Ткачука, який вважає, що безпосереднім предметом демократичного цивільного контролю у сфрері кібербезпеки має бути: дотримання вимог Конституції і законів України в діяльності органів сектора безпеки й оборони - суб'єктів національної системи кібербезпеки, недопущення порушення ними прав і свобод людини та громадянина у ході здійснення заходів із забезпечення кібербезпеки держави; зміст і стан реалізації Стратегії кібербезпеки України, Закону України "Про основні засади забезпечення кібербезпеки України", інших законів, підзаконних нормативно-правових актів, концепцій, державних програм та планів у сфері кібербезпеки; ефективність діяльності суб'єктів національної системи кібербезпеки, їхня укомплектованість відповідними фахівцями, оснащеність сучасними апаратно-програмними та технічними засобами, забезпеченість необхідними запасами матеріальних засобів і готовність до виконання завдань у сфері кібербезпеки у мирний час та в особливий період; ефективність використання ресурсів, зокрема бюджетних коштів, органами сектора безпеки і оборони під час здійснення заходів із забезпечення кібербезпеки держави [4, с. 119].

Отже, предмет демократичного цивільного контролю над силами оборони є елементом діяльності об'єктів контролю, який безпосередньо охоплений організаційною поведінкою як військових посадових осіб, так й інших категорій військовослужбовців та працівників військових формувань, а також цивільних осіб, які законами України наділені повноваженнями безпосередньо приймати рішення, що стосуються сил оборони. Предмет демократичного цивільного контролю над силами оборони має відповідати таким вимогам: об'єктивність, вимірюваність, конкретність, повторюваність результатів у разі застосування іншими суб'єктами контролю тієї самої методології контролю.

Аналіз чинного законодавства, яке регулює як безпосереднє здійснення контролю над силами оборони, так i їхнє функціонування, свідчить, що достатнього нормативно-правового підґрунтя для реалізації визначених вище вимог ще не створено. Із цього приводу заслуговує на увагу думка С. Крука, який вважає, що законодавче закріплення основних параметрів функціонування суб'єктів сектора безпеки з метою оцінки їхнього стану інституційної результативності. Відсутність системної конкретизації переліку та функцій органів державної влади унеможливлює оцінювання їхньої діяльності за результатами. Це фрактично робить невизначеними сферу відповідальності суб'єктів сектора безпеки і предмет демократичного цивільного контролю, який покликаний також долучатися до їхнього оцінювання. Зважаючи на це, автор вважає, що в розд. IV Закону України "Про національну безпеку України" слід закріпити параметри моніторингу й оцінювання інституційної результативності суб'єктів сектора національної безпеки України, а також особливості реалізації демократичного цивільного контролю в цьому контексті [5, с. 39]. Погоджуючись із позицією автора щодо недосконалості нормативно-правової бази здійснення демократичного цивільного контролю над силами оборони, зауважимо однак, що закріплення безпосередньо в законодавчому правовому акті всіх параметрів моніторингу та оцінювання суб'єктів сектора безпеки й оборони уявляється нам некоректним, оскільки це значно ускладнить користування таким правовим актом за рахунок значного збільшення його обсягу. Однак, безумовно, критерії оцінювання результатів контрольних заходів мають знайти своє нормативне закріплення. Враховуючи чинний порядок організації діяльності органів виконавчої влади та особливості розподілу компетенції між ними [6, с. 68-69], сучасний стан розвитку взаємодії між силами оборони та громадянським суспільством [7, с. 12-13], а також актуальну ситуацію у сфері протидії військовим злочинам та правопорушенням [8, с. 251-252], вважаємо, що документ, у якому мають знайти своє відображення критерії оцінювання сил оборони у процесі цивільного демократичного контролю, має бути затверджений на рівні рішення РНБО України і введений у дію Указом Президента України.

Висновки. Предмет демократичного цивільного контролю над силами оборони має джерелом свого походження суспільні відносини, які виникають у секторі безпеки та оборони. Співвідношення між об'єктом і предметом вказаного контролю обумовлюється масштабом діяльності, яка здійснюється для досягнення цілей контролю. При цьому предмет демократичного цивільного контролю над силами оборони завжди менше за своїм масштабом, ніж його об'єкт.

Прогалини у правовому регулюванні відносин, пов'язаних із контрольною діяльністю в секторі безпеки та оборони, вимагають свого заповнення. Вказане потребує внесення змін і доповнень до Закону України "Про національну безпеку", спрямованих на конкретизацію системи оцінювання результатів контролю за діяльністю сил оборони.

\section{Список використаної літератури}

1. Мулявка Д. Г., Гречанюк С. К., Федчишина В. В. Совершенствование социального контроля как направления предупреждения преступности // Всерос криминолог журн., 2019. № 13(3). С. 447-454. URL: http://cj.bgu.ru/reader/article. aspx?id=22984 (дата звернення 21.05.2021).

2. Захарченко Р.О., Теремцова Н.В. Правомірна поведінка та чинники її реалізації: проблемний аспект : зб. мат-лів // IX наук. читання, присвячені пам'яті акад. В.В. Копєйчикова (м. Київ, 20 лист. 2019 р.). С.74-78.

3. Молчанова А. О., Воляник І. В., Кондратьєва В. П. Організаційна поведінка : навч. посібн. / за наук. ред. А. О. Молчанової. Івано-Франківськ : "Лілея НВ", 2015. 176 с.

4. Ткачук Н.А. Демократичний цивільний контроль у сфері кібербезпеки : мат-ли панельної дискусії // Кримінальні загрози в секторі безпеки: практики ефективного реагування. III Харків. міжнар. юрид. форуму "Право", м. Харків, 26 верес. 2019 р.

5. Крук С. І. Розвиток державного управління у сфері забезпечення національної безпеки: від планування до контролю // Вісн. Нац. ун-ту цивільного захисту України. Серія "Державне управління", 2019. № 2(11). C. $37-43$.

6. Шопіна І.М. Щодо правової регламентації функціонування центральних органів виконавчої влади // Публічне право, 2011. № 3 . С. 65-71.

7. Коропатнік І.М. Взаємодія громадянського суспільства і Збройних сил України: адміністративно-правові засади : монографія. Київ : Леся, 2016. 412 c.

8. Остапенко І.О. Особливості провадження у справах про військові адміністративні правопорушення : тези доп. // Сучасні проблеми адміністративного права та процесу. Всеукр. наук.-практ. конф. (м. Харків, 30 черв. 2017 р.). С. 251-254.

\section{References}

1. Mulyavka, D.G., Grechanyuk, S.K., Fedchishina, V.V. (2019) Improving social control as a direction of crime prevention. All-Russian Criminological Journal, 13 (3), 447-454. URL: http://cj.bgu.ru/reader/ article. aspx?id=22984. [in Russian].

2. Zakharchenko, R.O., Teremtsova, N.V. (2019). Legitimate behavior and factors of its implementation: a problematic aspect. IX scientific readings dedicated to the memory of Academician V.V. Kopeychikova, 74-78. [in Ukrainian].

3. Molchanova, A.A., Volyanyk, I.V., Kondratieva, V.P. (2015). Organizational behavior: Textbook. Manual / for science. ed. A.A. Molchanova. [in Ukrainian]. 
4. Tkachuk, N.A. (2019). Democratic civilian control in the field of cybersecurity. Criminal threats in the security sector: practices of effective response: materials of the panel discussion. [in Ukrainian]

5. Kruk, S.I. (2019). Development of public administration in the field of national security: from planning to control. Bulletin of the National University of Civil Defense of Ukraine. Public Administration Series, 2 (11), 37-43. [in Ukrainian].

6. Shopina, I.M. (2011). Regarding the legal regulation of the functioning of central executive bodies. Public law, 3, 65-71. [in Ukrainian].
7. Koropatnik, I.M. (2016) Interaction of civil society and the Armed Forces of Ukraine: administrative and legal principles: a monograph. [in Ukrainian].

8. Ostapenko, I.O. Features of proceedings in cases of military administrative offenses. Modern problems of administrative law and process: thesis add. participants All-Ukrainian scientific-practical conf., 251-254. [in Ukrainian].

Надійшла до редколегії 20.07.21

D. Degtyarov, Senior Lecturer

mega.degdd@ukr.net

ORCID ID 0000-0002-2512-6967

Taras Shevchenko National University of Kyiv, Kyiv, Ukraine

\section{BODY OF DEMOCRATIC CIVILIAN CONTROL OVER THE DEFENSE FORCES}

The purpose of writing this article is to define the concept and features of democratic civilian control over the defense forces.

It was found that the legal relations that arise during the consolidation and definition of the subject of democratic civil control are complex and governed by the rules of various branches of law. To correctly determine the subject of the studied type of control, it is necessary to distinguish the external manifestations of activity of these officials, which are subject to measurement, generalization and analysis. One such manifestation is the behavior of persons subject to legislative provisions on the exercise of democratic civilian control over the defense forces. The subject of democratic civilian control over the defense forces is an element of the objects of control, which is directly covered by the organizational behavior of both military officials and other categories of servicemen and employees of military formations, as well as civilians empowered by Ukrainian law to make decisions. relating to the defense forces. The subject of democratic civilian control over the defense forces must meet the following requirements: objectivity, measurability, specificity, repeatability of results in the case of application by other subjects of control of the same control methodology. The subject of democratic civilian control over the defense forces has its source in the social relations that arise in the security and defense sector. The relationship between the object and the subject of the specified control is determined by the scale of activities carried out to achieve the objectives of control. At the same time, the subject of democratic civilian control over the defense forces is always smaller in scale than its object. An analysis of the current legislation governing the control of the defense forces shows that a sufficient legal basis for the implementation of the above requirements has not yet been created. Gaps in the legal regulation of security and defense control activities need to be filled. This requires amendments to the Law of Ukraine "On National Security", aimed at specifying the system of evaluation of the results of control over the activities of the defense forces.

Keywords: democratic civil control, defense forces, security and defense sector, legal support, legal regulation, object of control, subject of control, subjects of control.

УДК 342.9

DOI: https://doi.org/10.17721/1728-2217.2021.47.51-53

О. Зіборєва, асп.

ORCID ID 0000-0001-7566-4600

Міжрегіональна Академія управління персоналом, Київ, Україна

\section{ФОРМИ ПУБЛІЧНОГО АДМІНІСТРУВАННЯ ПІДГОТОВКИ КАДРІВ 3 ВИЩОЮ ВІЙСЬКОВОЮ ОСВІТОЮ ДЛЯ ЗБРОЙНИХ СИЛ УКРАЇНИ}

Запропоновано визначення поняття і видів форм публічного адміністрування підготовки кадрів 3 вищою військовою освітою для ЗСУ як способи зовнішнього вираження досягнення поставлених перед суб'єктами публічного адміністрування у вказаній сфері цілей, здійснювані правовими та позаправовими (організаційними) методами. Проаналізовано теоретичні підходи до проблеми сутності форм публічного адміністрування, виокремлено найбільш важливі їхні ознаки. Такі форми з урахуванням принципу розмежування за характером та правовою природою поділено на чотири основні види: а) нормотворча діяльність, спрямована на встановлення та конкретизацію прав, обов'язків та відповідальності суб'єктів навчального процесу у ВВН3 та військових навчальних підрозділах закладів вищої освіти; б) видання виконавчо-розпорядчих та правозастосовчих індивідуальних правових актів; в) здійснення юридично значущих дій з виданням офіційного документа; г) здійснення забезпечувальних дій, необхідних для підтримки діяльності з підготовки кадрів з вищою військовою освітою для ЗСУ (сюди належить широкий комплекс діяльності, пов'язаної з організаційно-управлінським, інформаційним, матеріально-технічним, кадровим, психологічним та іншими видами забезпечення підготовки офіцерських кадрів). Обгрунтовано, що форми публічного адміністрування підготовки кадрів з вищою військовою освітою для ЗСУ є невід'ємною частиною понятійного апарата публічного адміністрування в секторі безпеки та оборони. Онтологічна природа досліджуваних форм публічного адміністрування зумовлена необхідністю практичної реалізації правових приписів на нормативно-правовому та індивідуальному рівні для досягнення цілей правового регулювання (забезпечення обороноздатності держави шляхом підготовки необхідної кількості офіцерських кадрів, що мають необхідні для цього знання, вміння, навички та особисті якості). Обґрунтовано, що напрями подальших наукових досліджень мають охоплювати проблеми, які виникають під час реалізації правових та позаправових (організаційних) форм публічного адміністрування підготовки кадрів з вищою військовою освітою для ЗСУ, а також шляхи розв'язання вказаних проблем.

Ключові слова: публічне адміністрування, форми публічного адміністрування, підготовка кадрів, зсу, вища військова освіта, правові форми, позаправові форми, правове регулювання.

Постановка проблеми. За результатами огляду системи військової освіти в Міністерстві оборони України (2020) було встановлено, що наразі система військової освіти перебуває у фазі інтенсивної трансформації. Амбітне завдання - у максимально стислі строки досягти достатньої сумісності зі структурами держав-членів Альянсу, осучаснити бачення подальшого розвитку військової освіти - стимулює до пришвидшення імплементації стандартів НАТО, зокрема й у сфрері військової освіти і науки. Вмотивований прогнозованим кар'єрним зростанням та фахово компетентний військовослужбовець - запорука побудови сучасного професійного війська [1]. Вказане потребує активізації наукових досліджень, спрямованих на пошук оптимальних форм публічного адміністрування підготовки офріцерських кадрів для ЗСУ, результати яких знайшли б своє втілення у законотворчій роботі, й обумовлює актуальність та важливість теми цієї статті.

Аналіз останніх досліджень і публікацій. Проблематику сутності та структури форм публічного адміністрування розглядали у своїх роботах такі науковці, як: В. Біла, К. Бугайчук, В. Галунько, В. Колпаков, О. Кузь- 